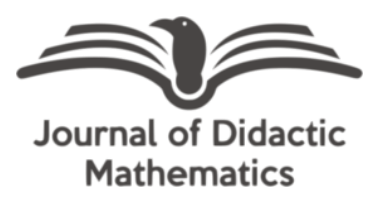

\title{
Hubungan resiliensi matematis terhadap kemampuan pemecahan masalah matematis mahasiswa pada mata kuliah matematika dasar
}

\author{
Ade Evi Fatimah* \\ STKIP Al Maksum, Langkat, Sumatera Utara, Indonesia, 20814
}

\section{Azrina Purba}

STKIP Al Maksum, Langkat, Sumatera Utara, Indonesia, 20814

\section{Yulia Anita Siregar}

Universitas Muhammadiyah Tapanuli Selatan, Padangsidimpuan, Sumatera Utara, Indonesia, 22716

*Corresponding Author: eviade997@gmail.com

\begin{abstract}
This study aims to determine the relationship and the extent of influence between mathematical resilience and students' mathematical problemsolving abilities in basic mathematics courses. This research is motivated by the perception of students who tend to be negative towards mathematics as well as an attitude of lack of confidence and easily give up in solving the given questions. In addition, students' mathematical solving abilities are also classified as low, even though this ability is very important because it is the basis and general goal of learning mathematics. The method used in this research is quantitative descriptive method. The population in this study were all Semester I students of the Computer and Informatics Engineering study program at STKIP AL Maksum Langkat which consisted of 5 classes and took basic mathematics courses, while the research sample was taken using purposive sampling technique, which is a technique of determining and taking the specified sample. by researchers with certain considerations. The sample consisted of 35 students. The instruments in this study were test questions in the form of mathematical problem-solving abilities and non-test questions in the form of a mathematical resilience scale. Then the data is processed using hypothesis testing techniques, correlation analysis and simple regression assisted by SPSS and Microsoft Excel. The results showed that there was a positive relationship between mathematical resilience and students 'mathematical problem-solving abilities with the effect of mathematical resilience by $41.3 \%$ on students' mathematical problem-solving abilities.
\end{abstract}

Historis Artikel:

Diterima: 2 Desember

2020

Direvisi: 4 Desember 2020

Disetujui: 30 Desember 2020

\section{Keywords:}

Mathematical Resilience, Mathematical Problem Solving Ability

Sitasi: Fatimah, A. E., Purba, A., \& Siregar, Y. A. (2020). Hubungan resiliensi matematis terhadap kemampuan pemecahan masalah matematis mahasiswa pada mata kuliah matematika dasar. Journal of Didactic Mathematics, 1(3), 151-157. Doi: $10.34007 /$ jdm.v1i3.470.

\section{PENDAHULUAN}

Mata kuliah Matematika Dasar merupakan mata kuliah wajib pada Program Studi Pendidikan Teknik Informatika dan Komputer di STKIP Al Maksum Langkat. Setelah mempelajari mata kuliah ini mahasiswa diharapkan mampu berpikir secara sistematis untuk mengatasi kesulitan dan memecahkan berbagai permasalahan matematika. Bernard (2015) menyatakan bahwa mata pelajaran Matematika perlu diberikan kepada seluruh peserta didik untuk membekalinya dengan kemampuan berpikir logis, sistematis, analitis, kritis, dan kreatif, serta kemampuan bekerja sama. Maharani (2018) tujuan pembelajaran matematika salah satunya adalah untuk mengasah cara berpikir dan bernalar peserta didik dalam menarik kesimpulan serta mampu mengungkapkan pendapatnya dengan percaya diri dan kejujuran yang timbul dari peserta didik untuk memecahkan masalah yang dihadapi. 
Menurut Peraturan Menteri Pendidikan dan Kebudayaan No.22 tahun 2016 (Kemendikbud, 2016) pemecahan masalah merupakan aspek yang harus menjadi bagian dari proses pembelajaran matematika dengan karakteristik saintifik, yang tercermin dalam rumusan standar proses pembelajaran. NCTM (Fatimah, 2018) juga mengemukakan bahwa pembelajaran matematika harusnya memungkinkan siswa membangun pengetahuan yang baru melalui pemecahan masalah, menyelesaikan masalah yang muncul dari matematika atau dalam konteks lain, menerapkan dan mengadaptasi berbagai pendekatan dan strategi yang sesuai untuk menyelesaikan masalah dan memonitor serta merefleksi pada proses pemecahan masalah matematis. Dengan demikian pembelajaran matematika harus selalu mengarah pada kemampuan pemecahan masalah bagi mahasiswa. Rahmmatiya (2020) menyatakan bahwa pemecahan masalah merupakan suatu usaha siswa dalam menyelesaikan masalah khususnya dalam pembelajaran matematika, yang menekankan pada penggunaan metode, prosedur, dan strategi yang dapat dibuktikan kebenarannya secara sistematis. Dalam matematika istilah pemecahan masalah mengacu pada tugas-tugas yang diberikan untuk meningkatkan pemahaman dan kemampuan matematis siswa. Selanjutnya Polya (Fatimah, 2020) mengemukakan empat langkah fase penyelesaian soal pemecahan masalah, yaitu: (1) memahami masalah; (2) merencanakan penyelesaian; (3) menyelesaikan masalah sesuai rencana; (4) melakukan pengecekan kembali terhadap semua langkah yang telah dikerjakan. Berdasarkan penelitian Netriwati (2016) secara umum hasil belajar aljabar linear (posttes) mahasiswa IAIN Raden Intan Lampung semester genap (2015-2016) dalam menyelesaikan masalah matematis dengan mengunakan teori polya meningkat dibandingkan dengan tes kemampuan awalnya (pretes). Hal ini diharapkan berlaku juga untuk mahasiswa Program Studi Pendidikan Teknik Informatika dan Komputer di STKIP Al Maksum Langkat.

Namun fakta di lapangan masih banyak mahasiswa yang mengalami kesulitan ketika belajar matematika, khususnya mata kuliah Matematika Dasar. Berdasarkan hasil wawancara dengan beberapa mahasiswa mereka mengatakan bahwa jika soal berbeda dengan contoh yang diberikan maka mahasiswa langsung bingung dan tidak bisa mengerjakan soal karena kurangnya pemahaman mereka terhadap masalah yang diberikan, kurangnya kemampuan dalam memodelkan masalah dalam soal, dan kurangnya perencanaan strategi dalam menyelesaikan soal matematika tersebut. Kejadian serupa juga ditemui dalam penelitian 'Athiyah (2020). Ini terjadi karena rendahnya kemampuan pemecahan masalah matematis mahasiswa. Selain itu sikap rasa percaya diri, kejujuran, ketangguhan, dan ketekunan mahasiswa dalam belajar matematika juga masih rendah. Sikap-sikap inilah yang menggambarkan kemampuan resiliensi matematis dari mahasiswa.

Grotberg (Zanthy, 2018) menyatakan bahwa resiliensi adalah kemampuan seseorang untuk menilai, mengatasi, dan meningkatkan diri ataupun mengubah dirinya dari keterpurukan atau kesengsaraan dalam hidup, karena setiap orang itu pasti mengalami kesulitan ataupun sebuah masalah dan tidak ada seseorang yang hidup di dunia tanpa suatu masalah ataupun kesulitan. Kemudian Johnston-Wilder (2010) menyatakan bahwa mahasiswa yang memiliki resiliensi matematis akan bertahan saat menghadapi kesulitan, akan berhasil secara kolaboratif dengan teman sebayanya, akan memiliki keterampilan bahasa yang dibutuhkan untuk mengekspresikan pemahaman dan akan memiliki teori pembelajaran yang berkembang. Sejalan dengan pernyataan Goodall (2015) mahasiswa dengan kemampuan resiliensi matematis memiliki keyakinan bahwa kemampuan mereka dalam bidang matematika akan tumbuh. Mereka melakukannya tidak memandang matematika sebagai sesuatu yang eksklusif, sebagai sesuatu yang dipahami orang lain saja tetapi mereka tidak, bahkan ketika mahasiswa itu sendiri mengalami kesulitan, dia akan mempertahankan kepercayaan dirinya dan sadar akan keberadaan dan kegunaannya hingga pada akhirnya sukses.

Dengan demikian terdapat dugaan bahwa kemampuan resiliensi matematis mempunyai hubungan dengan kemampuan pemecahan masalah matematis mahasiswa. Mahasiswa yang memiliki kemampuan resiliensi matematis yang tinggi akan mampu memecahkan masalah matematika karena sikap tekun dan gigih serta kepercayaan dirinya. Hal ini telah dibuktikan Dilla (2018) dalam penelitiannya yang menyebutkan bahwa semakin tinggi tingkat resiliensi matematis 
Hubungan resiliensi matematis terhadap kemampuan pemecahan...

siswa maka semakin tinggi kemampuan berpikir kreatifny. Berdasarkan latar belakang yang telah diuraikan di atas maka tujuan dari penelitian ini adalah untuk mengetahui hubungan antara resiliensi matematis dan kemampuan pemecahan masalah matematis mahasiswa. Cakupan topik dalam mata kuliah Matematika Dasar yang diujikan adalah materi persamaan dan pertidaksamaan linear.

\section{METODE}

Penelitian ini merupakan penelitian deskriptif kuantitatif untuk mengetahui terdapat atau tidaknya hubungan dan seberapa besar pengaruh variabel independen terhadap variabel dependen. Dalam hal ini variabel independen adalah resiliensi matematis dan variabel dependennya adalah kemampuan pemecahan masalah matematis mahasiswa. Subjek dalam penelitian ini adalah 35 orang mahasiswa program studi Pendidikan Teknik Informatika dan Komputer semester 1 STKIP Al-Maksum Langkat. Sedangkan objek penelitian adalah resiliensi matematis dan kemampuan pemecahan masalah mahasiswa.

Prosedur penelitian ini mempunyai 3 tahapan yaitu perencanaan, pelaksanaan, dan pelaporan. Pada tahap awal perencanaan kegiatan, hal yang dilakukan yaitu menyusun instrumen. Instrumen dalam penelitian ini adalah instrumen tes kemampuan pemecahan masalah matematis dan instrumen non tes, yaitu angket resiliensi matematis, serta melakukan uji instrumen untuk mengetahui validitas, reliabilitas, tingkat kesukaran dan daya pembeda dari setiap soal dengan menggunakan uji normalitas dan uji linieritas. Selanjutnya pada tahap pelaksanaan kegiatan, siswa diberi tes kemampuan pemecahan masalah dan pengisian angket resiliensi matematis. Kemudian pada tahap pelaporan dilakukan pengumpulan data dari tes pemecahan masalah dan angket resiliensi matematis yang diperoleh selama penelitian berlangsung, dan dianalisis dengan menggunakan teknik pengujian hipotesis analisis korelasi dan regresi sederhana berbantuan SPSS dan Microsoft Excel.

\section{HASIL DAN PEMBAHASAN}

Tujuan utama penelitian ini adalah untuk mengetahui hubungan dan besar pengaruh antara resiliensi dan kemampuan pemecahan masalah matematis mahasiswa pada mata kuliah matematika dasar. Berikut disajikan hasil penelitian berupa gambaran secara umum kemampuan resiliensi matematis dan kemampuan pemecahan masalah matematis mahasiswa, hasil uji korelasi untuk mengetahui seberapa besar hubungan antara kemampuan resiliensi matematis dengan kemampuan pemecahan masalah matematis mahasiswa, serta hasil uji signifikasi regresi untuk mengetahui besarnya pengaruh antara resiliensi matematis dengan kemampuan pemecahan masalah matematis mahasiswa yang mengampu mata kuliah matematika dasar.

\section{Deskripsi Resiliensi Matematis dan Kemampuan Pemecahan Masalah Matematis Mahasiswa}

Berikut dijabarkan deskripsi data hasil pencapaian resiliensi matematis dan kemampuan pemecahan masalah matematis mahasiswa PTIK yang mengampu mata kuliah Matematika Dasar.

Tabel 1. Gambaran Umum Resiliensi Matematis (RM) dan Kemampuan Pemecahan Masalah Matematis (KPMM) Mahasiswa

\begin{tabular}{lcrrrr}
\hline \multicolumn{1}{c}{ Variabel } & N & Minimum & Maximum & \multicolumn{1}{c}{ Mean } & Std. Deviation \\
\hline Resiliensi Matematis (RM) & 35 & 84 & 138 & 116 & 16.09 \\
Kemampuan Pemecahan Masalah & 35 & 67 & 100 & 83.90 & 7.941 \\
Matematis (KPMM) & & & &
\end{tabular}

Berdasarkan hasil perhitungan pada Tabel 1, maka dapat dilihat bahwa rata-rata dan standar deviasi resiliensi matematis mahasiswa masing-masing adalah 116 dan 16,09 terlihat nilai standar deviasi pada data resiliensi matematis siswa lebih rendah dari nilai rata-ratanya. Hal ini menunjukkan bahwa data resiliensi matematis tidak bervariasi, demikian juga halnya dengan 
kemampuan pemecahan masalah matematis siswa. Untuk kategori resiliensi matematis mahasiswa dijabarkan sebagai berikut.

Tabe1 2. Hasil Pencapaian Resiliensi Matematis Mahasiswa berdasarkan Kategori

\begin{tabular}{ccc} 
Batas (Interval) & Batas (Interval) & Kategori \\
$X<M-1 S D$ & $X<102$ & Resiliensi Rendah \\
$M-1 S D \leq X<M+1 S D$ & $102 \leq X<120$ & Resiliensi Sedang \\
$X \geq M+1 S D$ & $X \geq 120$ & Resiliensi Tinggi \\
\hline
\end{tabular}

Sumber: Sriffudin (Kurnia, 2018)

Berdasarkan Tabel 2 dapat dilihat bahwa resiliensi matematis mahasiswa pada mata kuliah Matematika Dasar berada pada kategori sedang. Hal ini berarti resiliensi pada mahasiswa cukup baik. Dengan kata lain, semakin baik resiliensi matematis mahasiswa maka akan semakin besar dalam mempengaruhi kemampuan pemecahan masalah matematis mahasiswa. Menurut Sugandi (2017) resiliensi matematik adalah faktor internal lain yang penting dalam pembelajaran matematika. Lebih lanjut Cahyani, Wulandari, Rohaeti \& Fitrianna (2018) menjelaskan bahwa resiliensi memiliki pengaruh yang besar terhadap ketercapaian kemampuan pemahaman matematis siswa. Berdasarkan pandangan ini, dapat disimpulkan bahwa dengan kemampuan resiliensi yang baik mahasiswa dapat menumbuhkan dan mengembangkan kemampuan pemecahan masalah matematis.

\section{Hubungan Resiliensi Matematis terbadap Kemampuan Pemecahan Masalah Matematis Mahasiswa}

Tujuan utama penelitian ini adalah untuk mengetahui hubungan dan besar pengaruh antara resiliensi matematis dengan kemampuan pemecahan masalah matematis mahasiswa PTIK pada mata kuliah Matematika Dasar. Untuk mengetahui hubungan antara resiliensi matematis dengan kemampuan pemecahan masalah matematis mahasiswa dilakukan analisis korelasi dan regresi sederhana. Adapun hasil pengujian terhadap hubungan kedua variable tersebut, yaitu variabel independen terhadap variabel dependen disajikan pada Tabel 3 berikut.

Tabel 3. Hasil uji korelasi resiliensi matematis dan kemampuan pemecahan masalah matematis

$\begin{array}{rrrrr}\text { Model } & \text { R } & \text { R Square } & \begin{array}{c}\text { Adjusted R } \\ \text { Square }\end{array} & \text { Std. Error of the Estimate } \\ 1 & .643^{\mathrm{a}} & .413 & .395 & 6.17452\end{array}$

Berdasarkan Tabel 3, dapat dilihat bahwa hubungan antara resiliensi matematis dengan kemampuan pemecahan masalah matematis mahasiswa sebesar 0,643. Johnston-Wilder, S. \& Lee, C. $(2008,2010)$ berpendapat bahwa resiliensi matematis adalah sebuah konsep penting dalam pendidikan, karena masih banyak pelajar yang mengalami kesulitan dan kegagalan dalam mempelajari matematika. Seseorang yang memiliki resiliensi matematis mempunyai kemampuan untuk menumbuhkan kepercayaan dirinya. Mereka menganggap bahwa matematika bukan suatu hambatan, bahkan ketika mereka sendiri mengalami suatu kesulitan, mereka dapat mempertahankan kepercayaan dirinya sampai berakhir sukses. Dia tidak akan segan membantu teman/kelompoknya berdasarkan pengetahuan yang dimilikinya dan dapat memanfaatkan bantuan dan dukungan temannya apabila diperlukan. Berdasarkan pandangan ini sangatlah jelas bahwa ketika seseorang memiliki kepercayaan diri sesulit apapun masalah yang dihadapinya ia akan mencoba untuk menemukan solusi apakah melalui pengetahuannya sendiri ataupun melalui bantuan orang dewasa. Untuk klasifikasi hubungan antar resiliensi matematis dan kemampuan pemecahan masalah matematis mahasiswa dapat dilihat pada Tabel 4 berikut.

Tabel 4. Guilford Empirical Rules

\begin{tabular}{cc}
\hline Skor & Kategori \\
\hline $0,00<r<0,20$ & Hubungan sangat lemah (diabaikan, dianggap tidak ada) \\
$0,20 \leq r<0,40$ & Hubungan rendah \\
$0,40 \leq r<0,70$ & Hubungan sedang/cukup
\end{tabular}


Hubungan resiliensi matematis terhadap kemampuan pemecahan...

$\begin{array}{lc}0,70 \leq r<0,90 & \text { Hubungan kuat/tinggi } \\ 0,90 \leq r \leq 1,00 & \text { Hubungan sangat kuat/tinggi }\end{array}$

Sumber: Lestari \& Yudhanegara (Iman \& Firmansyah, 2019)

Berdasarkan Tabel 4 dapat diartikan bahwa tingkat hubungan antara resiliensi matematis dan kemampuan pemecahan masalah matematis mahasiswa PTIK yang mengampu mata kuliah Matematika Dasar adalah sedang atau cukup. Kemudian dari Tabel 3 diperoleh bahwa nilai $R$ Square sebesar 0,413, sehingga besar pengaruh resiliensi matematis terhadap kemampuan pemecahan masalah matematis adalah sebesar $0,413 \times 100 \%=41,3 \%$. Keadaan ini berarti kemampuan pemecahan masalah matematis mahasiswa dipengaruhi resiliensi matematis sebesar $41,3 \%$ dan 58,7\% dipengaruhi oleh faktor lain. Untuk hasil uji signifikansi regresinya dapat dilihat pada Tabel 5.

Resiliensi matematis merupakan sikap ketahanan sesorang dalam menghadapi masalah matematis, sehingga dengan resiliensi seseorang akan mampu menyelesaikan permasalahan yang dihadapinya karena sesorang tersebut telah memahami dengan baik apa tujuan dan manfaat yang akan diperolehnya ketika mampu menghasilkan solusi dari permasalahan yang dihadapinya. Namun juga untuk memaksimalkan kemampuan mahasiswa secara optimal, perlu diperhatikan factor-faktor lain diluar resiliensi matematis, seperti latar belakang mahasiswa yang datang dari berbagai sekolah dan jurusan dan juga tingkat kesulitan matematika yang merupakan momok bagi sebagian besar orang. Anita (2014) menyatakan bahwa matematika yang dianggap momok bagi seseorang dapat menumbuhkan kecemasan saat ia berhadapan dengannya.

Tabel 5. Hasil Uji Koefisien Regresi

\begin{tabular}{rlrrrrr}
\multicolumn{7}{c}{ ANOVA $^{\mathrm{a}}$} \\
\hline Model & & Sum of Squares & $\mathrm{df}$ & Mean Square & \multicolumn{1}{c}{ F } & Sig. \\
\hline \multirow{3}{*}{1} & Regression & 886.053 & 1 & 886.053 & 23.241 & $.000^{\mathrm{b}}$ \\
& Residual & 1258.116 & 33 & 38.125 & & \\
& Total & 2144.168 & 34 & & & \\
\hline
\end{tabular}

a. Dependent Variable: Kemampuan Pemecahan Masalah Matematis

b. Predictors: (Constant), Resiliensi Matematis

Hasil dari Tabel 5 menunjukkan bahwa koefisien regresi signifikan karena diperoleh harga $F_{\text {hitung }}=23,241$ dan nilai signifikansi $0,000<0,05$, artinya ada pengaruh positif antara resiliensi matematis terhadap kemampuan pemecahan masalah matematis mahasiswa PTIK yang mengampu mata kuliah Matematika Dasar. Hasil penelitian ini sejalan dengan Zanthy (2018) yang menyatakan bahwa terdapat hubungan yang positif dan signifikan antara resiliensi matematis dengan kemampuan akademik mahasiswa. Resiliensi matematis memiliki kontribusi sebesar 48,5\% terhadap kemampuan akademik mahasiswa dan 51,5\% dipengaruhi oleh variabel lainnya. Kemudian Maharani (2018) juga menyebutkan dalam penelitiannya bahwa ada hubungan yang signifikan antara mathematical resilience dan kemampuan pemecahan masalah matematis. Dengan adanya resiliensi matematis yang baik dalam pembelajaran maka akan mempengaruhi kemampuan pemecahan masalah matematis mahasiswa khususnya yang mengampu mata kuliah mata kuliah Matematika Dasar.

Pada penelitian ini, tidak begitu besar pengaruh yang diberikan resiliensi matematis terhadap kemampuan pemecahan masalah matematis mahasiswa PTIK yang mengampu mata kuliah Matematika Dasar. Salah satu penyebabnya adalah karena bentuk kegiatan pembelajaran secara online/daring. Selain resiliensi matematis banyak faktor lain yang mempengaruhi kemampuan pemecahan masalah matematis. Faktor lain tersebut adalah seperti model pembelajaran online/daring Blended Learning menggunakan Edmodo (Yanti, 2019), kemandirian belajar (Ansori, 2019), dan kecemasan matematika (Riski, 2019). Berdasarkan hasil penelitian yang telah dilakukan dapat disimpulkan bahwa seseorang yang memiliki kepercayaan diri dan ketahanan yang baik dalam menghadapi masalah, akan memiliki kecenderungan untuk mencoba mencari solusi ketika dihadapkan pada permasalahan bahkan yang sulit sekalipun. Oleh karenanya perlu menjadi perhatian bagi kita bagaimana untuk menumbuhkan dan mengembangkan resiliensi matematis, 
agar para peserta didik baik siswa ataupun mahasiswa dapat mengoptimalkan kemampuannya dalam mencapai tujuan pembelajaran.

\section{KESIMPULAN}

Kesimpulan dari temuan penelitian yang diperoleh adalah terdapat hubungan yang positif dan signifikan antara resiliensi matematis dengan kemampuan pemecahan masalah matematis mahasiswa prodi PTIK pada mata kuliah Matematika Dasar. Sedangkan klasifikasi hubungan antar resiliensi matematis dan kemampuan pemecahan masalah matematis mahasiswa adalah dalam kategori sedang. Namun untuk memaksimalkan kemampuan mahasiswa perlu diperhatikan factorfaktor lain yang terkait seperti latar belakang mahasiswa, karakteristik materi, dan iklim pembelajaran selama proses pembelajaran berlangsung. Resiliensi matematis yang ditelaah pada penelitian ini merupakan resiliensi matematis yang terkait dengan kemampuan pemecahan masalah matematis mahasiswa pada mata kuliah Matematika Dasar. Peneliti selanjutnya diharapkan dapat meneliti resiliensi matematis yang terkait dengan kemampuan matematis dan materi lainnya.

\section{DAFTAR PUSTAKA}

Anita, I. W. (2014). Pengaruh kecemasan matematika (mathematics avxiety) terhadap kemampuan koneksi matematis siswa SMP. Infinity Journal, 3(1), 125-132.

Ansori, Y. dan Herdiman, I. (2019). Pengaruh kemandirian belajar terhadap kemampuan pemecahan masalah matematis siswa SMP. Journal of Medives: Journal of Mathematics Education IKIP Veteran Semarang, 3(1), 11-19.

'Athiyah, F., Umah, U., \& Syafrudin, T. (2020). Pengaruh mathematical resilience terhadap kemampuan pemecahan masalah matematis siswa. JKPM (Jurnal Kajian Pendidikan Matematika), 5(2), 223-234.

Bernard, M. (2015). Meningkatkan kemampuan komunikasi dan penalaran serta disposisi matematik siswa SMK dengan pendekatan kontekstual melalui game Adobe Flash CS 4.0. Jurnal Infinity, 4(2), 197-222.

Cahyani, E. P., Wulandari, W. D., Rohaeti, E. E., \& Fitrianna, A. Y. (2018). Hubungan antara minat belajar dan resiliensi matematis terhadap kemampuan pemahaman matematis siswa kelas VIII SMP. Jurnal Numeracy, 5(1), 49-56.

Dilla, S. C., Hidayat, W., \& Rohaeti, E. E. (2018). Faktor gender dan resiliensi dalam pencapaian kemampuan berpikir kreatif matematis siswa SMA. Journal of Medives: Journal of Mathematics Education IKIP Veteran Semarang, 2(1), 129-136.

Fatimah, A. E. (2020). Upaya peningkatan kemampuan pemecahan masalah matematis siswa MTs melalui model pembelajaran kooperatif tipe STAD. Journal of Didactic Mathematics, 1(1), 3340.

Fatimah, A. E., \& Purba, A. (2018). Pengembangan lembar aktivitas siswa (LAS) menggunakan pendekatan differentiated instruction untuk meningkatkan kemampuan pemecahan masalah matematis siswa SMK. MES (Journal of Mathematics Education and Science), 4(1), 1-9.

Goodall, J., \& Johnston-Wilder, S. (2015). Overcoming Mathematical Helplessness and Developing Mathematical Resilience in Parents: An Illustrative Case Study. Creative Education, 6, 526-535;

Iman, S. A. dan Firmansyah, D. (2019). Pengaruh Kemampuan Resiliensi Matematis terhadap Hasil Belajar Matematika. Prosiding Seminar Nasional Matematika dan Pendidikan Matematika Sesiomadika. 356-360;

Johnston-Wilder, S., \& Lee, C. (2008). Does Articulation Matter When Learning Mathematics? Proceedings of the British Society for Research into Learning Mathematics, 28, 54-59.

Johnston-Wilder, S., \& Lee, C. (2010). Developing Mathematical Resilience. In: BERA Annual Conference 2010, September 1-4, 2010, University of Warwick.

Kemendikbud. (2016). Peraturan Menteri Pendidikan dan Kebudayaan No.22 tahun 2016.

Kurnia, H. I., Royani, Y., Hendriana, H., Nurfauziah, P. (2018). Analisis kemampuan komunikasi 
Hubungan resiliensi matematis terhadap kemampuan pemecahan...

matematik siswa SMP di tinjau dari resiliensi matematik. JPMI - Jurnal Pembelajaran Matematika Inovatif, 1(5), 933-940.

Maharani, S., \& Bernard, M. (2018). Analisis hubungan resiliensi matematik terhadap kemampuan pemecahan masalah siswa pada materi lingkaran. JPMI - Jurnal Pembelajaran Matematika Inovatif, 1(5), 819-826.

Mawaddah, S., \& Anisah, H. (2015). Kemampuan pemecahan masalah matematis siswa pada pembelajaran matematika dengan menggunakan model pembelajaran generatif (generative learning) di SMP. EDU-MAT Jurnal Pendidikan Matematika, 3(2), 166-175.

Netriwati. (2016). Analisis kemampuan pemecahan masalah matematis berdasarkan teori polya ditinjau dari pengetahuan awal mahasiswa IAIN Raden Intan Lampung. Al-Jabar: Jurnal Pendidikan Matematika, 7(2), 181-190.

Rahmmatiya, R., \& Miatun, A. (2020). Analisis kemampuan pemecahan masalah matematis ditinjau dari resiliensi matematis siswa SMP. Teorema: Teori dan Riset Matematika, 5(2), 187-202.

Riski, F, et al. (2019). Pengaruh kecemasan matematika terhadap kemampuan pemecahan masalah siswa di sma. Gauss: Jurnal Pendidikan Matematika, 2(2), 11-23.

Sugandi, I. K. (2017). Meningkatkan kemampuan berpikir kreatif dan resiliensi matematis siswa SMP melalui pendekatan generatif. Jurnal Perspektif Pendidikan, 11(2), 70-77.

Sugiyono. (2015). Metode Penelitian Kombinasi (Mixed Methods). (Sutopo, Ed.). Bandung: ALFABETA.

Yanti, F. N, et al. (2019). Analisis kemampuan pemecahan masalah matematis: Dampak blended learning menggunakan edmodo. Desimal: Jurnal Matematika, 2(2), 173-180.

Zanthy, L. S. (2018). Kontribusi resiliensi matematis terhadap kemampuan akademik mahasiswa pada mata kuliah statistika matematika. Jurnal Mosharafa, 7(1), 85-94. 